Sari, S.A., Khatimah, K. (2015). The Application of School Watching Method to Increase the Earthquake Disaster Preparedness of Primary School Students, MIN Blang Mancung, Aceh. Journal of Education and Learning. Vol. 9(3) pp. 241-245.

\title{
The Application of School Watching Method to Increase the Earthquake Disaster Knowledge of Primary School Students
}

Sri Adelila Sari

Faculty of Teacher Training and Education, Syiah Kuala University, Indonesia

Husnul Khatimah $^{* *}$

Disaster Science Postgraduate Program, Syiah Kuala University, Indonesia

\begin{abstract}
The study entitled "The Application of School Watching to Increase the Earthquake Disaster Knowledge of Primary School Students, MIN Blang Mancung, Aceh” was aimed to describe the students' knowledge of the different dangerous objects in the face of an earthquake. The approach used in this study was qualitative and quantitative. The type of study was descriptive. Subjects used were as many as 30 students MIN Blang Mancung, Aceh. The method used was an experimental, which was divided into two classes, namely the experimental and control classes. Data collection technique was using questionnaires, which included the questions about common dangerous objects, dangerous objects in the class and also in the school yard. The results showed that there was a significant effect on students' knowledge before and after the implementation of the method School Watching. In addition, the knowledge of students toward the dangerous objects was found to be significant different between control and experimental class.
\end{abstract}

Keywords: School watching, disaster, and preparedness

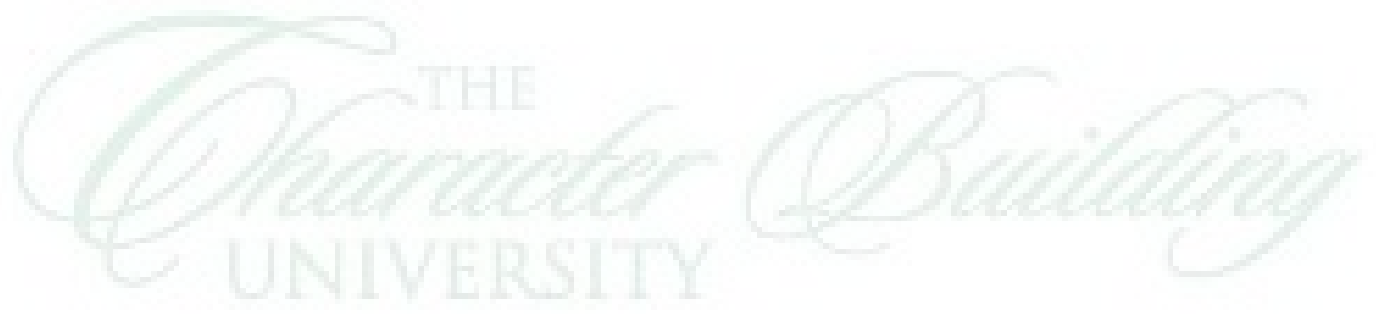

*Sri Adelila Sari, S.Pd., M.Si., Ph.D, Lecturer at Faculty of Teacher Training and Education, Syiah

Kuala University, Banda Aceh, Indonesia.

E-mail: sriadelilasari@unsyiah.ac.id

*** Husnul Khatimah, S.Pd, M.Si, Disaster Science Postgraduate Program, Syiah Kuala University,

Banda Aceh, Indonesia.

E-mail: husnulkhatimah.ms@gmail.com

Received May 22, 2015; Revised June 22, 2015; Accepted July 10, 2015 


\section{Introduction}

Preparedness is need not only for facing the disaster but also to reduce the number of victims. There is one way to do such as identify what is the objects that will dangerous when the disasters occur especially in earthquake. As Sari, et.al., (2014) explained that one of the place that will make more victims when disasters occur is school. Because in the class rooms, its common to place some trophys, souveniers for something that already achieve. Besides that, class room is also used to keep student books, vase and other wall hanging, in purposing to help student in memorizing the lessons. However, all the matters could be also as of the dangerous object for students. Earthquake that recently occurs because of plate's movement can make an effects in the earth surface. It's not only make an object around us falls down but also it also can make victims, especially in school. It is happen because the lackness of knowledge about preparedness when facing the disasters.

Based on the observation that conducted in August, 2014 in MIN Blang Mancung, the school did not have socialization yet about disasters, in lesson by the teacher or the institutions. Therefore, it was interested to study the knowledge about the earthquake disaster of MIN Blang Mancung students. The knowledge can be taught through extracurricular activity so the student know how to act when disaster happen and it also help to reduce the number of victims. The school watching was the possible one of the extracurricular activities could be implemented.

\section{School Watching}

\section{Literature Review}

School watching is a method that can be help the student and school to increase disasters preparedness by doing an activity such as make a list about the objects that will be dangerous when earthquake happen. In the other hand, town watching activity aims to be a tool of city planning but now can be use as the orientation of disaster prevention. After finding the dangerous places, disaster prevention facilities and town heritages, disasters is acknowledge as the thing that is need a concern by the communities. So the increasing about awareness of disasters prevention need by doing such as the activity based on disasters. Town watching must be beginning by primary students and junior high school students with the cooperation of teachers, parents, civil servant, worker and volunteers (Shaw and Takeuchi, 2009). Campus watching is also an interesting methods by doing the directly activity to see the real conditions of location and identify if the area is dangerous or not when the disasters happen (Rahman, 2012).

\section{The Steps of School Watching}

There is a few steps for school watching activity to identify object and place that might be dangerous when earthquake occurs (LPPM-ITB, 2002), such as :

1) Explain to students when earthquake occur it is rarely cause death or injury. The cause death or injury most likely because of the object that might be dangerous around them.

2) Explain the background and aims of the activity to students.

3) Tell the student to open an appendix that is show a dangerous object or place.

4) Tell the student to determine an object or place that they think it is dangerous such as in the class or around school.

5) Make a discussion to explain why the object or place are dangerous for them when disaster happen.

6) Tell the student to open a sketch of class.

7) In that sketch, tell the student to daw or deterime where is the dangerous object and place when earthquake occur.

8) Tell the student to open a sketch about their school.

9) In that sketch, tell the student to daw or deterime where is the dangerous object and place when earthquake occur.

10) Give a group of students to make a sketch of their class and school also tell them to draw with an object around class and school.

11) Based on the sketch, make a discussion to determine where is the dangerous object for student

12) When disasters occur.

13) Based on the list of dangerous object in class or around school, student can make an earthquake evacuation route

14) Tell one of the student for giving presentation about their work in front of class. 


\section{Knowledge}

Education is a good example to do an activity based on earthquake preparedness starting from kindergarten to university. Especially in the school, most of the victims is the children because they didn't know how to act when the disaster occur. School is consider as the best place for transformation knowledge about disaster preparedness, so the student can learn and apply it in their lives. Knowledge is the important thing for facing disaster that nowadays occur. Knowledge not only can be obtain in school but also can be obtain from the experiences or by local wisdom. Rahman, et.al., (2014) stated that one of the most important thing for community is how to gain or create new knowledge in the museum for the community. Local wisdom is a culture that can made a knowledge have more meaning against disaster that already occurred before. Knowledge that we obtain from cultures can teach us how to act against disasters. As Paton, et.al., (2013) explained that the cultures can be identify in significally toward preparedness, action and values of the community process. Students need a guidance not only how they know and understand about what is a disaster but also they have to know how they can manage in disaster preparedness and more responsive until they can minimalize the risk of disasters.

\section{Earthquake}

Earthquake is one of the disasters that cannot be predicted when it will occur. The magnitude of this disaster is also different often greater than before. Earthquake is one of natural disasters that it causes by natures. As it state by Lesmana, (2014) the phenomenon that cause by nature is it called natural disaster such as earthquakes, tsunamis, volcanoes, floods, droughts, cyclone sand landslides. As it often state that the cause of earthquake because of plate movements so it can make and effect on the earth surface. The earthquake is a vibration or sudden movement under earth surface that might be cause by plate movement when the pressure already too great (Baroroh, et.al., 2008).

\section{Research Method}

This study was conducted in MIN Blang Macung, Aceh from Desember 2014 to February 2015. The approaches of this study were qualititive and quantitative. The type of this study was descriptive. The population was all students of MIN Blang Mancung, Aceh. The number of sample was about 30 students from fifth grade class as an experiment class and forth grade class as control class taken by purposive sampling.

The data were collected using questionnaire and analysed by statistical analysis using the Eq. (1) which was stated by Sudijono (2010):
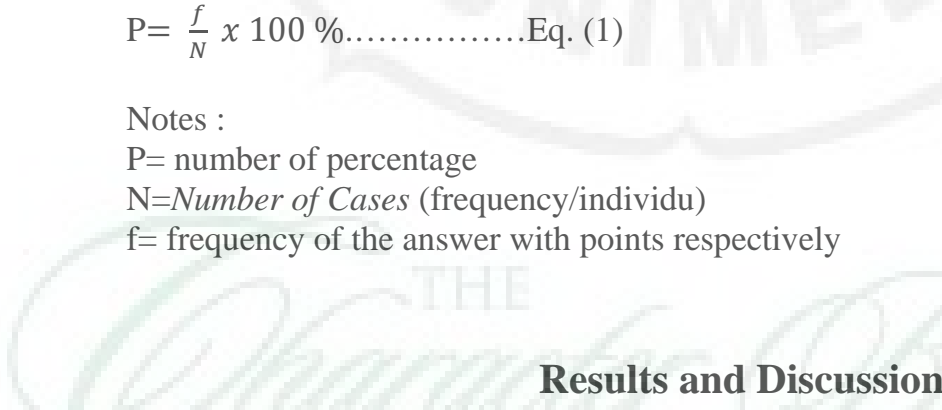

\section{Students' Knowledge about Dangerous Objects When Earthquake Occur}

There were two classes used in this study, i.e. control and experimental class to see application of methods school watching toward dangerous object against earthquake. In the control class data was conduct by giving the questionnaire about dangerous objects without the school watching activity. The pre test and post test were given to compare the knowledge of the students before and after the implementation of school watching method. It has been found that 40 percent of students thought that some objects were not dangerous for them. However, it was increased to 80 percent after the implementation of the school watching. Some methods could help the knowledge of the students in terms of earthquake disaster, such as e-learning and audio visual as well. Sari, et.al., (2014) found that the precentage of disaster knowledge of the students using e-learning was found to be 76.2 and the rest was of 23.8 percent, respectively. This study concluded that the student knowledge was increase by using e-learning methods. In addition Pritanto, (2010) stated that there was an increasing of understanding in community about disaster mitigation after using audio visual 
media from with from 5.70 to 8.24 percent. Therefore, some methods or media could be used to increasing the knowledge about disasters.

\section{Students' Knowledge about Dangerous Object in the Class}

Some objects usual put into the class room are president poster, shelves, also vase and recycle bin. Before school watching method was implemented, it has been found that about 36.67 percent of students answered the questionnaire with the blackboard was not the dangerous object. However, after school watching method is applied, about 86.67 percent of students answered that blackboard was the dangerous one. It was matched with the theory that there is a different of knowledge between the student that already given the knowledge and not. The other study done by Afifah, et.al., (2014) also found that 83.9 percent of responden from 52 people had lack knowledge toward earthquake. But after the respondent was given the knowledge, there was an increasing of knowledge percentage of the respondents.

\section{Student Knowledge about Dangerous Object around the School Yard}

Some dangerous objects around the school yard were also included in the questionnaire. Based on answer of students, it has been found that 36.67 percent students answered that flagpole and gates were not dangerous objects when the earthquake occurs. It might be due the lackness of knowledge about that. In addition, it has been found that all of the students (100 percent) answered that the class room was the most dangerous place if a great earthquake occur. On the other hand, the percentage of knowledge was also increased up to 96.67 percent for water tank. According to Sugiyono, (2014) who stated that creating the new methods could be increasing student knowledge from 37.5\% to $92.5 \%$. The increasing of knowledge of student toward dangerous object after the simulation and make list about dangerous object could make the student feel the real condition if disaster occur, so the student could be avoid it. It was like Rinanda, (2013) stated that by make a study using method could be increased the children attention for learning and gain a knowledge.

Based on statistical analyses using t-test for the knowledge of dangerous objects, it was found that there was a significant different about students' knowledge on dangerous objects before and after implemented of school watching. It was also shown that the knowledge of student in control class was lower than in experimental class. It might be due to in control class students were not given such information about earthquake. However, in experimental class, most of students had got real experiences in facing earthquake in year 2013.

\section{Conclusions and Suggestions}

\section{Conclusions}

The knowledge of MIN Blang Mancung students toward common dangerous objects, dangerous objects in the class and dangerous objects in the school yard could be increased by implementing the school watching method. Based on the t-test analyses, there was a significant different knowledge about dangerous objects between experimental and control class.

\section{Suggestions}

Based on the study, therefore some suggestions are drawn below: (i) Timing must be managed more efficiently for school watching implementation, and (ii) Further study should be done in terms of earthquake disaster preparedness, especially for the students in all levels.

\section{Acknowledgement}

The acknowledgements submitted to the Directorate of Research Community Service, the Directorate General of Higher Education, Ministry of Education and Culture, Indonesia for funding this study. 


\section{References}

Afifah, V.A., Istichomah, dan Priyanti, W. 2014. Pengaruh Pendidikan Kesehatan Tentang Kesiapsiagaan Bencana Gempa Bumi Terhadap Pengetahuan Siswa di SDN Patalan Baru Kecamatan Jetis Kabupaten Bantul. J. Kesehatan Samodra Ilmu. Vol. 5, No. 2.

Baroroh, A. 2008. Dampak Gempa Bumi Tektonik Bagi Kehidupan Masyarakat Kepuh Wetan Wirokerten Banguntapan Bantul. Skripsi. Yogyakarta: Universitas Sunan Kalijaga.

Lesmana, I. 2014. Efektivitas Kelembagaan Badan Penanggulangan Bencana Daerah (BPBD) Kabupaten Kutai Barat Dalam Pelaksanaan Tugas Pokok Dan Fungsinya. eJournal Pemerintahan Integratif. Vol. 2, No. 1

LPPM-ITB, Departemen Pendidikan Nasional, Direktorat Jendral Pendidikan Dasar dan Menengah, dan UNICEF. 2002. Program Kesiapsiagaan Sekolah Terhadap Bahaya Gempa Bahan Ajar Guru. Jakarta: DEPDIKNAS.

Paton, D., Okada, N., and Sagala, S. 2013. Understanding Preparedness for Natural Hazard: A Cross Cultural Comparison. Journal of Integrated Disaster Risk Management. Vol. 3, No. 1.

Pristanto, A.I. 2010. Upaya Peningkatan Pemahaman Masyarakat Tentang Mitigasi Bencana Gempa Bumi Di Desa Tirtomartani Kecamatan Kalasan Kabupaten Sleman Provinsi Daerah Istimewa Yogyakarta. Skripsi. Yogyakarta: Universitas Negeri Yogyakarta.

Rahman, A., Sari, S.A., and Ridha, M. 2014. The Development Aceh Tsunami Museum Documentary on SECI Model of Knowledge Management. The International Journal of Social Sciences. Vol. 19, No. 1.

Rahman, M. 2012. Analisis Jalur Evakuasi Pada Gedung Graha Sainta Universitas Brawijaya Sebagai Upaya Mitigasi Bencana Angin Topan Dengan Menggunakan Metode Campus Watching. J. Erudio. Vol. 1, No. 1

Sari, S.A., Dirhamsyah, M., and Finzia, P.Z. 2014. The Influence of Earthquake Disaster Risk Reducation Simulation Towards The Preparedness Knowledge For Elementary School Student Of Ulee Paya, Pulo Breuh, Aceh Besar, Indonesia. International Journal of Education and Research. Vol. 2., No. 8.

Sari, S.A., Dirhamsyah, M., Milfayetty, S., and Rahmaty. 2014. E-Learning Material Development on Earthquake In Geography Subject for High School Students. International Journal of Education and Research. Vol. 2, No. 8.

Shaw, R., and Takeuchi, Y. 2009. Town Watching Handbook for Disaster Education Enhancing Experiental Learning. Japan : Kyoto University.

Sudijono, A. 2003. Pengantar Statistik Pendidikan. Jakarta : Raja Gravindo Persada.

Sugiyono. 2014. Metode Penelitian Pendidikan Pendekatan Kuantitatif, Kualitatif, dan $R$ \& D. Bandung : Alfabeta. 